\title{
The Role of Ulil Amri and Religious Authorities in Determining Public Policies Related to the Syariah Rulings in Malaysia: A Study on the COVID- 19 Pandemic
}

\author{
${ }^{i *}$ Lukman Abd Mutalib, iWan Abdul Fattah Wan Ismail, iAhmad Syukran Baharuddin, iAbdul \\ Manan Ismail, 'Mohd Soberi Awang, iSetiyawan Gunardi, iiSiti Fatimah Salleh, 'Muhammad Hazim \\ Ahmad \\ ${ }^{\mathrm{i}}$ Fakulti Syariah dan Undang-undang, Universiti Sains Islam Malaysia, Nilai \\ ${ }^{i i}$ Fakulti pengajian kontemporari Islam, Universiti Sultan Zainal Abidin, Kampus Gong Badak, 21300 Kuala Nerus, Terengganu \\ *(Corresponding author) email: lukman@usim.edu.my
}

\begin{abstract}
Every action related to the people must be evaluated, scrutinized, and approved by Ulil Amri before it is allowed to be implemented by the Islamic religious authorities at their respective state. This study was conducted with the aim of identifying Ulil Amri who is responsible for handling and managing COVID-19 pandemic issues. In addition, this study was also conducted to identify the role and job scope of each Ulil Amri involved in formulating the public policies related to the COVID-19 pandemic. This qualitative study has collected relevant data through primary and secondary documents and further analysed them using the content analysis method. The results of this study found HM DYMM Yang di-Pertuan Agong and Rulers, State Council of Islamic Religion, State Mufti Department, and State Islamic Religious Council. They are the Ulil Amri who is responsible for handling and managing COVID-19 pandemic issues related to Islamic religious affairs in Malaysia. Each Ulil Amri involved has their own role and jurisdiction. They will work together in formulating any public policy related to Islamic religious affairs. This shows that every public policy produced involves various parties from various fields who work together to safeguard the maslahat and prevent mafsadah from happening to the people.
\end{abstract}

Keywords:

Public policy, Role of Ulil Amri, COVID-19 pandemic, Islamic religious affairs, Maslahat and mafsadah Article Received: 18 October 2020, Revised: 3 November 2020, Accepted: 24 December 2020

\section{Introduction}

Every action related to the people must be evaluated, scrutinized, and approved by Ulil Amri before it is allowed to be implemented by the Islamic religious authorities at their respective state. This matter is based on the concept of Siyāsah Syar'iyyah which stipulates that all rulings made by ulil amri should be with the aim of preserving the welfare of the people ( $\mathrm{Pa}$, Basir, \& Mohamed, 2010; Zalani \& Omar, 2019). This has also been clearly stated in a prophetic tradition narrated by Ibn Umar (r.a.), as to the effect:

Ibnu Umar (r.a.) narrated: I heard Messenger of Allah (p.b.u.h.) saying, "All of you are guardians and are responsible for your wards. The ruler is a guardian and responsible for his subjects; the man is a guardian and responsible for his family; the woman is a guardian and is responsible for her husband's house and his offspring; and so all of you are guardians and are responsible for your wards." [Reported by alBukhari, tradition no. 5200; and Muslim, tradition no. 1829 \& 20]

This prophetic tradition refers to each person having their obligation to maintain and carry out the trust and confidence that has been entrusted to him (al-Nawāwī, 2010; al-Suyūțī, 1996). As for the context of Ulil Amri, Mullā 'Ali al-Qārī (2002) and al-Munāwī (1988) said that the mandate given to them is in the form of the people including matters and rights related to it are all subjected under their responsibility. Each of these trusts, confidence, and responsibilities should be carried 
out fairly. They must also take care of the welfare of their dependents in terms of this world (dunyawi) and the Hereafter (ukhrawi). In fact, all these dependents will be reviewed and reassessed in the hereafter whether the person entrusted is successful or fails to carry out all the burdens given (al-Munāwī, 1937).

\section{Methodology}

This qualitative study uses documentary research methods to evaluate books written by scholars and academics. In addition, the same methodology is also used to evaluate the results of the latest studies reported in quality and indexed journals. Documentary research methods are used to obtain and collect relevant data through documents, writing, and records that have been produced (Neely \& Ponshunmugam, 2019; Prior, 2008). The main purpose of this method is to scientifically evaluate written documents whether public or private documents (Payne \& Payne, 2004; Walsh, 2014). For the purpose of this study, we evaluated both types of documents. In this study, we have used some key documents such as Al-Quran, books of hadith such as Șahịh alBukhārī by al-Bukhāri (2002) and Sahịh Muslim by M. A. H. Muslim (2016), the Federal Constitution, the National Security Council Act 2016 (Act 776), and the Prevention and Control of Infectious Diseases Act 1988 (Act 342). These documents are used to identify the jurisdiction and jobs scope that have been allocated for each Ulil Amri in Malaysia. In addition, this study has also referred to major commentary books such as Jāmi' al-Bayān fì Ta'wīl al-Qur'ān by al-Ṭabarī (2000), al-Jāmi li Ahkām al-Qur'ān by al-Qurțubī (1964), Mafātih al-Ghayb by Fakhruddin al-Rāzī (1999), and Tafsir al-Qur'ān al-'Azīm by Ibnu Kathir (1999) to obtain the interpretation of ulil amri according to the scholars. We have determined that the data from these documents is the primary data because this data is from a direct source, reliable and not influenced by the views or opinions of individuals. Furthermore, the data from these books have been a source of reference for scholars in later times to this day.

Next, the secondary data for this study is a discussion of the general role of government at the central and state levels in facing the COVID-19 pandemic as well as their specific role in determining public policies related to Islamic religious affairs. In addition, secondary data is also obtained from writing in indexed journals especially Scopus and WOS obtained from the Scopus database accessed through the EZproxy portal of Universiti Sains Islam Malaysia.

Then, the data obtained were analyzed using content analysis methods to understand and extract the important and useful information that is around the text of the document (Leavy, 2017). Since this study is a qualitative work, then the content analysis in this study has been implemented inductively (Julien, 2008). This process is implemented repeatedly (recursive) involving the process of data collection and analysis related to the application of definitions, rules, or procedures for continuous results (Hayes, Navarro, Stephens, Ransom, \& Dilevski, 2019; Leavy, 2017; Liew, Grisham, \& Hayes, 2018).

\section{Findings and discussion}

The findings of this study and the discussion on it are divided into three parts, namely the determination of Ulil Amri in the COVID-19 pandemic in Malaysia, their role and general responsibility towards Malaysians, and the challenges in formulating such policies.

\section{Ulil Amri involved in the construction of a general policy related to the Syariah rulings in COVID-19 Pandemic}

The Muslim exegetes have differed on the interpretation of Ulil Amri which can be divided into four categories (al-Qurțubī, 1964; al-Ṭabarī, 2000; Ibnu al-Jawzī, 2001). 


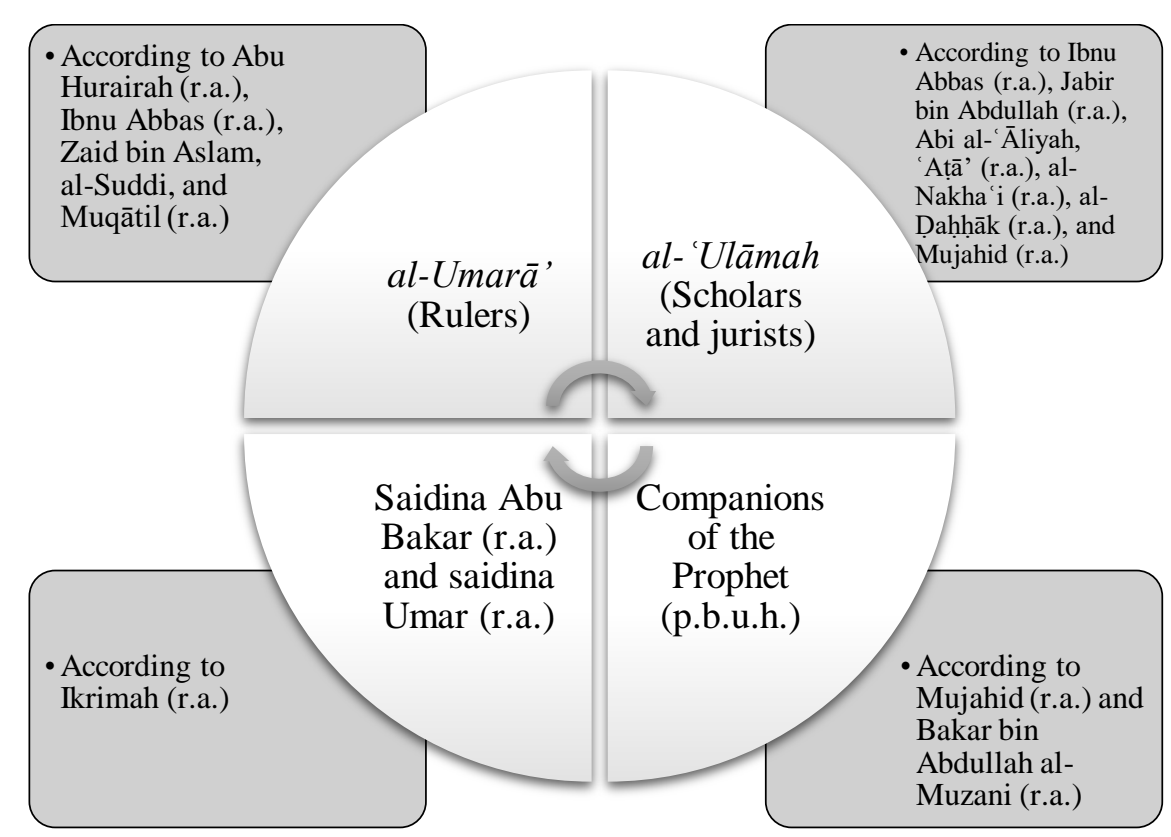

Figure 1: Interpretation of Ulil Amri among the Muslim exegetes (al-Qurțubī, 1964; al-Ṭabarī, 2000; Ibnu al-Jawz̄, 2001)

Figure 1 above summarizes the four interpretations of Ulil Amri among the Muslim exegetes on verse 59 of Surah al-Nisa. Despite the differences, al-Ṭabarī (2000) explained that alUmara ${ }^{\prime}$ (Rulers) is the most accurate interpretation. This is based on some authentic tradition from the Prophet (p.b.u.h.) who ordered Muslims to obey the command of the rulers so long it brings benefits for Muslims. Among the traditions meant by al-Ṭabarī (2000) are as narrated by Ibnu 'Umar (r.a.):

Ibnu 'Umar (r.a.) narrated: The Prophet (p.b.u.h.) said, "It is obligatory upon a Muslim to listen (to the ruler) and obey whether he likes it or not, except when he is ordered to do a sinful thing; in such case, there is no obligation to listen or to obey." [Reported by al-Bukhari, tradition no. 7144; and Muslim, tradition no. 1839, 38]

Furthermore, the interpretation of Ulil Amri as alUmara ' (Rulers) is a more appropriate and relevant in the context of administration and statehood (Ilyas, 2011; Kadir, 2014). In other words, Ulil Amri is the governing authority of a country and be given the power to govern the affairs of its people. They have been given the mandate to address various social issues and problems in a country.

Originally, Ulil Amri in governance related to religious affairs was the HM DYMM Yang diPertuan Agong and Sultan. Therefore, any determination of Islamic affairs or Islamic law in the state is within their jurisdiction (Bahrom, 2019; N. Muslim \& Buang, 2012). Later, these duties, and responsibilities were delegated to several state government agencies in order to systematically facilitate and expedite the administration of Islamic affairs. Delegation of authority, duties, and responsibilities refers to the process of giving authority to a person or group to make decision and take action in a particular situation (Balwi, Sarif, \& Lubis, 2018). 


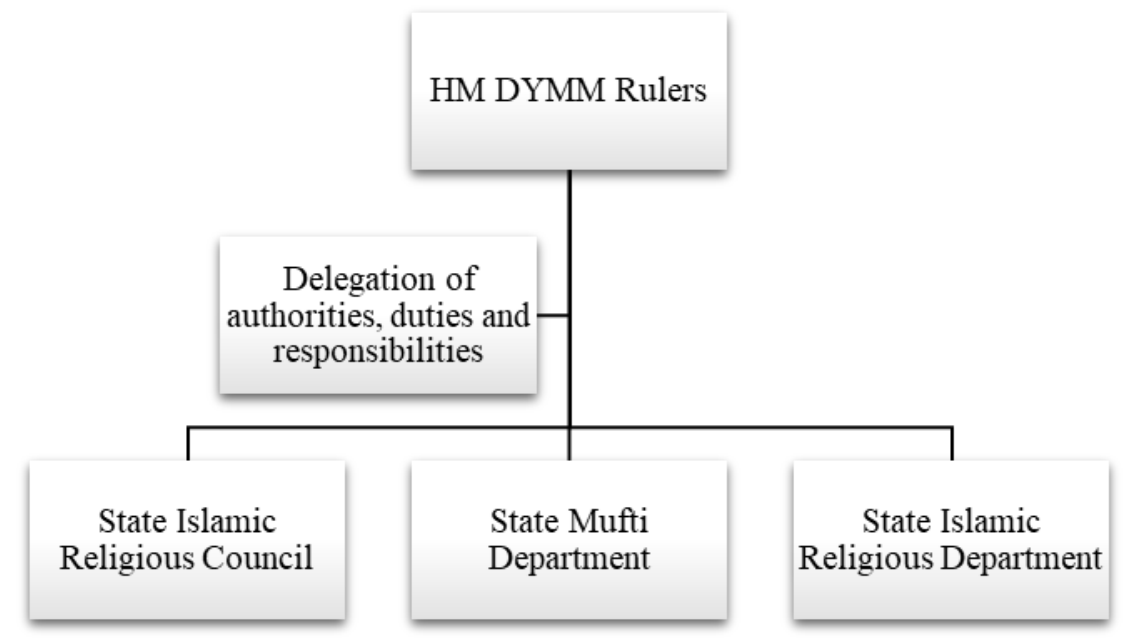

Figure 2: Delegation of authorities, duties, and responsibilities

Figure 2 above illustrates the delegation of authorities, duties, and responsibilities from the Rulers to the state government agencies. Furthermore, these agencies are specifically involved in the determination of public policy related to the Syariah rulings on the COVID-19 pandemic. The State Islamic Religious Council will assist and advise the Ruler in relation to all matters relating to Islam in his territory, except matters relating to Islamic law and those relating to the administration of justice as it are the duty of the State Mufti Department.

Among the general roles of the State Islamic Religious Council are to formulate policies, effectively and dynamically certify policies related to Islamic affairs decided by Islamic religious agencies at the federal level, as well as consistently monitor and coordinate the implementation of Islamic policies and fatwas made by the implementing bodies at the state level. Meanwhile, Mufti at the State Mufti Department is religious adviser Raja Melayu and has the authority and ability to issue fatwas on contemporary issues. As for the State Islamic Religious Department, it will enforce all the public policies set by the State Islamic Religious Council.

The role and responsibility of Ulil Amri in confronting the COVID-19 Pandemic
Since the COVID-19 pandemic hit Malaysia, the Minister in the Prime Minister's Department (Religious Affairs), the Aṣhābus Samāhahh muftis, the State Islamic Religious Council, and the State Islamic Religious Department, always discuss to reach a decision to issue opinions, fatwas, or public policies with the goal in preserving the welfare of Muslims (Bahaudin, 2020; Ruzki, 2020). A series of national and state Fatwa Committee Meetings was held to discuss the relevant and reasonable measures that can be done by taken into account the current situation in Malaysia (Bahaudin, 2020; Ruzki, 2020).

In formulating the public policy regarding Syariah rulings related to COVID-19 pandemic in Malaysia, the Ulil Amri should bear in mind about the backbone principle ordained by Syarak that is to maintain the public interests and avoid them from any harm (al-Āmidī, 2003; al-Ghazāli, 2015; Ibnu Abdul Salam, 2020). This is in accordance with the Islamic legal maxim, as articulated by Tājuddin al-Subkī (1991), al-Suyūṭi (2013), alZarkashī (1985) and al-Zarqā (2012), "attașarrufu 'alār-ra '̄yyati manūtun bil-mașlahah" (acts of those with authority over people must take into account the interests of the people). This maxim denotes that the action of stakeholders, public service, politicians, and anyone who is served as a guardian over something or someone, should be subject to fulfilling the legitimate interests of those for whom they are responsible 
(Shabīr, 2007; Zaydān, 2015). Such legitimate interest should be matters that are consistent with the Syariah higher intents (maqāṣid al-syarī‘ah) and not the matters which are forbidden (al-Burnu, 2002).

Next, Ulil amri should also refer to health experts, especially the Ministry of Health Malaysia (MOH) and the security forces, especially the National Security Council (MKN). This is based on the words of God in surah an-Nahl verse 43:

\section{"if ye realise this not, ask of those who} possess the Message” (Quran 16: 43)

The above verse commands the laymen to make reference on the knowledgeable person (ahlaz. zikri) or individual known for his knowledge and skills (al-khabìr) for matters that are beyond their expertise (Abu al-Su ūd, n.d.; al-Shawkānī, 2000; Fakhruddin al-Rāzī, 1999). In cases related to COVID-19 pandemic, the knowledgeable group or experts are the $\mathrm{MOH}$ and in terms of maintaining the safety of the people is the MKN. These two parties are called al-khabìr or those who are experts for us to refer to him (Mohamad, 2020). Prior to the development of a public policy, ulil amri must first obtain from the $\mathrm{MOH}$ and $\mathrm{MKN}$ the detailed and thorough information regarding the transmission of the COVID-19 pandemic in Malaysia including reports of current data, facts, and statistics.

There is also a long story narrated by Ibn Abbas where Umar al-Khattab (RA) held a shura together with other companions (RA) to decide whether to continue the journey to Syria or turn back to Medina. This event was recorded during the transmission plague of 'Amwas in Syria province on $18 \mathrm{H} / 639 \mathrm{M}$. This narration was reported by al-Bukhari, tradition no. 5729; and Muslim, tradition no. $2219 \& 98$. According to alNawāwī (2010), this tradition elucidates the necessity to perform shurā together with various parties from different backgrounds and expertise. Furthermore, researchers are of the opinion that such elucidation also highly recommended in confronting the current COVID-19 pandemic. In this regard, we are referring to the maxim "the ruling of a certain matter depends on the understanding of the issue" (al-hukm 'alāl-syai' $i$ far'un 'an tașauwurihi). By this maxim, understanding on the real situation is emphasized by Syarak before a certain rulings or policy can be issued to govern such situation. The real situation of COVID-19 pandemic can be understood thoroughly by holding several discussions and meetings with the expertise from $\mathrm{MOH}$ and MKN. In fact, this action can prevent the occurrence of al-tasāhul (latitude and indulgence) in issuing a ruling or policy. According to al-Nawawi (2016), espousing al-tasāhul in ruling or policy is clearly forbidden. $\mathrm{He}$ also explained that al-tasāhul means being too hasty in issuing a ruling or policy without ascertaining the validity of the verdict and without due consideration and study.

In addition, Ulil Amri must ensure that the public policy to be built is in line with the Syariah main principle, which is, implementing the concept of careful prevention to halt the spread of lifethreatening pandemic. This is derived from the following tradition, where Abdul Rahman bin Auf has said:

\section{I heard the Prophet (p.b.u.h.) saying, "If you get wind of the outbreak of plague in a land, you should not enter it; but if it spreads in the land where you are, you should not depart from it." [Reported by al-Bukhari, tradition no. 5729; and Muslim, tradition no. $2219 \& 98]$}

This event was narrated by Ibn Abbas (r.a.) where at that time, saidina Umar al-Khattab (r.a.) held a shura together with other companions (r.a.) to decide whether to continue the journey to Syam which was hit by the plague of 'Amwas or turned back to Medina. There happened to come Abdul Rahman bin Auf who was initially had been absent for some of his needs, and delivered what has he heard from the Prophet (p.b.u.h.) saying on the pertaining matter. This story contains 
prohibitory injunction on the people to enter the area of the outbreak as well as banning them from leaving without valid reason and escaping the area of the disease (al-Bughā, al-Khin, al-Sharbaj̄̄, Mistu, \& Lutfi, 2014; Ibnu 'Ilān, 2019). According to Ibnu Qayyim al-Jauziyyah (1994), this is the best cause of action in dealing with disease outbreaks. According to him, when the Prophet (p.b.u.h.) forbids the entrance to the occurrence of an outbreak and out of the occurrence of the disease, he actually incorporated an optimal disease prevention system. In other words, this story has given us the impression that when an outbreak occurs, then the main methodology that the Prophet (p.b.u.h.) suggests to us is focusing on the preventive measures.

Then, Ulil Amri is also responsible for making a public policy that is in line with the requirements of the Quran and Sunnah. This can be highlighted through the application of several Islamic legal maxims that are closely related to the COVID-19 pandemic. Among the maxims that need to be used in the determination of the general policy are as follows:

\begin{tabular}{|c|c|}
\hline $\begin{array}{l}\text { Blocking the Means } \\
\text { (Sadd al-Dharāi }{ }^{\text {) }}\end{array}$ & $\begin{array}{l}\text { - This maxim refers to the need to block the means that can lead to harm. } \\
\text { Doing physical distancing is amounting to block the means that can bring } \\
\text { harm such as COVID-19 infection on humanity. }\end{array}$ \\
\hline 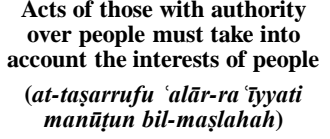 & $\begin{array}{l}\text { - This maxim refers to the actions taken by the government against the } \\
\text { people depend on the maslahah. In this context, the government has the } \\
\text { right to make decisions based on the welfare of the people in accordance } \\
\text { with the Islamic principles. }\end{array}$ \\
\hline $\begin{array}{l}\text { Harm shall neither be inflicted } \\
\text { nor reciprocated } \\
\text { (Lā Darara wa La } \bar{a} \text { Dirāra) }\end{array}$ & $\begin{array}{l}\text { - This maxim aims to prevent a person from doing harm to himself and } \\
\text { causing harm to others. Exposing oneself to COVID-19 infection can cause } \\
\text { harm to oneself and transmit the virus to others. This is prohibited because } \\
\text { it exposes to death due to infection with this virus. Physical distancing } \\
\text { during congregational prayers in mosques and suraus as stipulated in the } \\
\text { public policy is in accordance with this maxim. The transmission of this } \\
\text { virus is a harm that must be eliminated by breaking the chain of } \\
\text { transmission. From this maxim, it is obligatory to remove the harm. }\end{array}$ \\
\hline $\begin{array}{l}\text { Harm is to be eliminated as far } \\
\text { as possible } \\
\text { (al-Darar Yuzäl bi-Qadari al- } \\
\text { Imkän) }\end{array}$ & $\begin{array}{l}\text { - This means that any effort that is truly serious and effective with all efforts } \\
\text { to eliminate harm and also to prevent it from happening is regarded as } \\
\text { obligatory by the Syarak. }\end{array}$ \\
\hline $\begin{array}{l}\text { Severe harm is removed by } \\
\text { lesser harm } \\
\text { (al-Dararal-Asyad Yuzäl bil- } \\
\text { Darari al-Akhaf) }\end{array}$ & $\begin{array}{l}\text { - This means that originally, Islam forbade any form of harm as well as } \\
\text { matters that cause harm. If in order to eliminate a severe harm by having } \\
\text { to cause lesser harm, then the Syariah permits actions that caused lesser } \\
\text { harm in order to eliminate and prevent from severe harm from happening. }\end{array}$ \\
\hline
\end{tabular}

Figure 3: Islamic legal maxims related to implementation of public policy

Figure 3 above illustrates among the applicable Islamic legal maxims in developing a certain public policy concerning with the Syariah rulings related to COVID-19 pandemic. The application Islamic legal maxims into the public policy are very important to ensure the well-being of Muslims. In addition, this action can also meet Islamic requirements by keeping the benefit of Muslims in Malaysia, as well as preventing them from any harm while doing any religious affairs.

Challenges in formulating and enforcing the public policy
Every Ulil Amri and religious authorities work together in formulating a general policy related to Islamic religious affairs. Nevertheless, there are some challenges that arise in the formulation of this policy such as jurisdiction conflicts between the authorities at the federal and state levels. This happens when the jurisdiction in matters of national security and the prevention of infectious diseases collides with the jurisdiction related to the determination of Islamic religious affairs in the states. Conflict often occurs when the NSC and $\mathrm{MOH}$ have set an SOP related to the Movement Control Order (PKP) which is 
enforced, the standard operating procedure (SOP) is implemented at the discretion of the state religious authority whether to practice it in whole, in part, or according to suitability. MKN and $\mathrm{MOH}$ are indeed the backbone in governing the affairs of Malaysians, especially when confronting with the COVID-19 pandemic. Every action performed is based on the National Security Council Act, 2016 (Act 776) and the Prevention and Control of Infectious Diseases, 1988 (Act 342). However, when it comes to actions involving Islamic religious affairs in Malaysia, then, absolute power is given to the state authorities in administering all matters related to Islam in their respective states. This is clearly stated in item 1, List II - State List under the Ninth Schedule of the Federal Constitution. This indicates that the state authorities have the right to act at their discretion in making any determination of Islamic affairs or Islamic law in their state.

This study suggests that the determination of general policies related to religious affairs in Malaysia, especially in the COVID-19 pandemic, should be submitted to Ulil Amri and religious authorities in a state. Nevertheless, they need to take into account the advice given by the MKN and $\mathrm{MOH}$ in determining the public policy. This is because item 7, List III - Concurrent List in the Ninth Schedule of the Federal Constitution has provided for public health, sanitation, and the prevention of diseases as a common jurisdiction between the federal and state governments. This shows that maintaining public health, sanitation, as well as preventing the spread of disease are among the jurisdictions shared by the two types of governments. Therefore, in exercising their jurisdiction, the MKN and $\mathrm{MOH}$ need to advise the Ulil Amri and religious authorities in a state regarding matters involving public safety, public health, and disease prevention. Similarly, Ulil Amri and religious authorities, in exercising their jurisdiction, need to take into account the advice given by the MKN and $\mathrm{MOH}$ when it comes to develop a public policy related to Islamic religious affairs.

\section{Conclusion}

In conclusion, there are several Ulil Amri who are responsible for handling and managing COVID19 pandemic issues in Malaysia. As for the determination of the public policy related to Islamic affairs, they are comprised of the Head of the religion of Islam, namely the HM DYMM YDPA and sultan, State Islamic Religious Council, Mufti at the State Mufti Department, and State Islamic Religious Council. Each of them has a general and specific role for the people under their jurisdiction. Their general role is to manage the administration of all affairs and welfare of the people in accordance with the concept of safeguarding the welfare and rejection of the harm that will befall them. Next, each Ulil Amri has a role and jurisdiction either at the central or state level. They cooperate in establishing a common policy related to Islamic affairs. This form of cooperation is also in line with the practice of shura as advocated by Islam. This practice can prevent the occurrence of al-tasāhul (latitude and indulgence) in issuing a ruling or policy. This study suggests that when there is a clash between the jurisdiction among Ulil Amri, then the power of Ulil Amri and state religious authorities should take precedence because they are the ones who should make any determination of Islamic affairs or Islamic law in their state. Nevertheless, they need to take into account the advice given by the MKN and $\mathrm{MOH}$ because maintaining public health and preventing diseases are among the jurisdictions shared by Ulil Amri and state religious authorities with the central government.

\section{Acknowledgment}

This study expresses our appreciation of the full funding provided by the Research \& Innovation Management Center, Universiti Sains Islam Malaysia (USIM) through the USIM COVID-19 Research Grant scheme, PPPI/COVID19_0120/FSU/051000/15820, titled, "Pembangunan Garis Panduan Penetapan Hukum Syarak Dari Aspek Muamalat Dalam Situasi COVID 19 Di Malaysia Berasaskan Maqasid Syariah". Acknowledgements were also 
expressed to the research members, as well researchers Center of Research for Fiqh Forensics and Judiciary (CFORSJ), Islamic Science Institute, Universiti Sains Islam Malaysia (USIM) for their cooperation.

\section{References}

[1] Abu al-Su 'ūd, M. M. (n.d.). Irshād al- 'Aq1 al-Salīm ilā Mazāyā al-Qur'ān al-Karīm (Vol. 5). Cairo: Dar al-Mushaf Maktabah wa Matba'ah Abdul Rahman Muhammad.

[2] al-Āmidī, A. M. (2003). al-Iḥkām fĩ Uṣūl al-Aḥkām (A. R. Afifi Ed. 1 ed. Vol. 3). Riyadh: Dar al-Șami'i.

[3] al-Bughā, M., al-Khin, M., al-Sharbajī, A., Mistu, M., \& Lutfi, M. A. (2014). Nuzhat al-Muttaqīn Sharḥ Riyāạ al-Ṣāliḥīn min Kalām Sayyid al-Mursalīn (1 ed.). Damascus: Muasasat al-Risalah Nasyirun.

[4] al-Bukhāri, M. I. (2002). Șaḥị̣ al-Bukhārī (1 ed.). Damascus: Dar Ibnu Kathir.

[5] al-Burnu, M. S. A. (2002). al-Wajīz fì Idah Qawā'id al-Fiqh al-Kuliyyah. (5th ed.). Beirut: Dar al-Risalah Al-'Alamiah.

[6] al-Ghazāli, M. M. (2015). al-Mustașfā min 'Ilmi al-Ușūl (M. S. al-Ashqar Ed. 1st ed. Vol. 1). Beirut: Mu'asasat al-Risalah Nasyirun.

[7] al-Munāwī, M. A. R. T. A. (1937). Fayḍ al-Qaḍīr bi-Sharḥ al-Jāmi al-Ṣaghīr (1st ed. Vol. 5). Egypt: Maktabah al-Tijariyyah al-Kubra.

[8] al-Munāwī, M. A. R. T. A. (1988). alTaysīr bi-Sharḥ al-Jāmic al-Ṣaghīr (3rd ed. Vol. 2). Riyadh: Maktabah al-Imam alShafi $\overline{1}$.

[9] al-Nawawi, Y. S. (2016). al-Majmū' fì Sharh al-Muhazzab (M. N. al-Muțīī Ed. 2 ed. Vol. 1). Egypt: al-Tawfikiya Bookshop.

[10] al-Nawāwī, Y. S. (2010). al-Minhāj Sharaḥ Șahịḥ Muslim bin al-Hajjāj (M. Mara'ī Ed. 1st ed. Vol. 4). Damascus: Dar al-Fayha'.
[11] al-Qurțubī, M. A. (1964). al-Jāmi` li Ahkām al-Qur'ān (A. al-Barduni \& I. Atfish Eds. 2nd ed. Vol. 5). Cairo: Dar alKutub al-Misriah.

[12] al-Shawkānī, M. A. (2000). Fatḥ al-Qadīr al-Jāmi' Bayna Fannayyi al-Riwāyah wa al-Dirāyah min 'Ilmi al-Tafsīr (1st ed.). Beirut: Dar Ibnu Hazm.

[13] al-Suyūṭ̂̄, A. R. A. B. (1996). al-Dībāj 'ala Șaḥị Muslim bin al-Hujjāj. Al Khobar: Dār Ibn 'Affān li al-Nashr wa al-Tawzì'.

[14] al-Suyūṭī, A. R. A. B. (2013). al-Ashbah wa al-Nazā'ir fì Qawā'id wa Furū' alShāfi iyyah (M. M. Tahir \& H. A. Hafiz Eds. 6 ed.). Cairo: Dar al-Salam.

[15] al-Ṭabarī, M. J. (2000). Jāmi' al-Bayān fī Ta'wīl al-Qur'ān (A. M. Syakir Ed. 1st ed. Vol. 8). Cairo: Muassasah al-Risālah.

[16] al-Zarkashī, M. A. (1985). al-Manthūr fì al-Qawā' id al-Fiqhiyyah (2 ed.). Kuwayt: Wizarah al-Awqaf al-Kuwaytiyah.

[17] al-Zarqāà, A. M. (2012). Sharḥ al-Qawā' id al- Fiqhiyyah (10th ed.). Damascus: Dar al-Qalam.

[18] Bahaudin, N. H. (2020, 15 Mac). Hukum Covid-19 akan disampaikan kepada Agong, Sultan dan Raja. myMetro. Retrieved from https://www.hmetro.com.my/mutakhir/202 0/03/554924/hukum-covid-19-akan-

disampaikan-kepada-agong-sultan-dan-raja

[19] Bahrom, H. (2019). Perlembagaan: Isu Perlaksanaan Undang-undang Islam. Jurnal Syariah, 7(1), 79-96.

[20] Balwi, M. A. W. F. M., Sarif, S., \& Lubis, A. (2018). Authority Delegation In Organization: Lessons from 7th Century Early Islamic Era Jurnal al-Tamaddun, 13(1), 1-11.

[21] Fakhruddin al-Rāzī, M. O. (1999). Mafătih al-Ghayb (3rd ed. Vol. 10, 20). Beirut: Dar Ihya al-Turath al-Arabi.

[22] Hayes, B. K., Navarro, D. J., Stephens, R. G., Ransom, K., \& Dilevski, N. (2019). The diversity effect in inductive reasoning depends on sampling assumptions. 
Psychonomic Bulletin \& Review, 26(3), 1043-1050.

[23] Ibnu Abdul Salam, A. A. A. S. (2020). Qawā id al-Aḥkām fī Iṣlāḥ al-Anām (N. K. Hammad \& O. J. a. Damiriyyah Eds. 6 ed. Vol. 1). Damascus: Dar al-Qalam.

[24] Ibnu al-Jawzī, A. R. A. (2001). Zād alMasīr fì 'Ilmi al-Tafsīr (A. R. al-Mahdī Ed. 1st ed. Vol. 1). Beirut: Dar al-Kitab al'Arabi.

[25] Ibnu 'Ilān, M. A. M. '. (2019). Dalīl alFāliḥin li-Ṭarqi Riyāọ al-Șāliḥīn (D. S. Yahya Ed. 1 ed. Vol. 5). Damascus: Dar al-Faiya'.

[26] Ibnu Kathir, I. U. (1999). Tafsir al-Qur'ān al-'Azīm (S. M. Salamah Ed. 2nd ed. Vol. 2). Riyadh: Dar Thaibah.

[27] Ibnu Qayyim al-Jauziyyah, M. A. B. (1994). Zād al-Ma'ād fì Hadȳ̄ Khayr al'Ibād (27th ed. Vol. 4). Beirut: Mu'asasat al-Risalah.

[28] Ilyas, Y. (2011). Ulil Amri dalam Tinjauan Tafsir. Jurnal Tarjih, 12(1), 43-50.

[29] Julien, H. (2008). Content Analysis. In L. M. Given (Ed.), The Sage Encyclopedia of Qualitative Research Methods (Vol. 1, pp. 120-122). California: SAGE Publications, Inc.

[30] Kadir, M. N. A. (2014). Keabsahan Ulilamri dengan Kaedah Rampasan Kuasa dalam Aspek Maqasid Syariah. Jurnal Hadhari, 6(2), 85-96.

[31] Leavy, P. (2017). Research Design: Quantitative, Qualitative, Mixed Methods, Arts-Based, and Community-Based Participatory Research Approaches. New York: The Guilford Press.

[32] Liew, J., Grisham, J. R., \& Hayes, B. K. (2018). Inductive and deductive reasoning in obsessive-compulsive disorder. Journal of Behavior Therapy and Experimental Psychiatry, 59, 79-86.

[33] Mohamad, Z. (2020). Soal Jawab Fiqh COVID-19 - Edisi Kemas Kini. Retrieved from MIRA - Pejabat Menteri Di Jabatan Perdana Menteri (Hal Ehwal Agama) website:

https://mira.gov.my/wpcontent/uploads/2020/09/FIQH-

COVID_Kemas-Kini-1_compressed-1.pdf

[34] Mullā 'Ali al-Qārī, A. S. M. (2002). Mirqāt al-Mafātịh Sharh Mishkāt alMașābīh (1st ed. Vol. 6). Beirut: Dar alFikr.

[35] Muslim, M. A. H. (2016). Șaḥị̣ Muslim (Y. Hasan, I. Dalli, \& I. al-Tiyar Eds. 2 ed.). Damascus: Mu'asasat al-Risalah Nasyhirun.

[36] Muslim, N., \& Buang, A. H. (2012). Islam dalam Perlembagaan Persekutuan dari Perspektif Hubungan Etnik di Malaysia. Jurnal Kemanusiaan, 10(2), 115-129.

[37] Neely, A. H., \& Ponshunmugam, A. (2019). A qualitative approach to examining health care access in rural South Africa. Social Science and Medicine, 230, 214-221.

[38] Pa, B. C., Basir, S. A., \& Mohamed, S. (2010). Perlaksanaan Siyāsah Syar'iyyah dalam Pentadbiran di Malaysia. Jurnal alTamaddun, 5(1), 57-72.

[39] Payne, G., \& Payne, J. (2004). Key Concepts in Social Research. London: SAGE Publications Ltd.

[40] Prior, L. F. (2008). Document Analysis. In L. M. Given (Ed.), The Sage Encyclopedia of Qualitative Research Methods (Vol. 1, pp. 230-231). California: SAGE Publications, Inc.

[41] Ruzki, R. M. (2020, 15 Mac). Muzakarah khas bincang hukum berkaitan COVID-19. BH Online. Retrieved from https://www.bharian.com.my/berita/nasion al/2020/03/665632/muzakarah-khasbincang-hukum-berkaitan-covid-19

[42] Shabīr, M. O. (2007). al-Qawā'id alKulliyah wa al-Ḍawābiṭ al-Fiqhiyyah. Beirut: Dar al-Nafa'is.

[43] Tājuddin al-Subkī, A. W. A. (1991). alAshbāh wa al-Naz̄āiir (1 ed. Vol. 1). Beirut: Dār al-Kutub al-'Ilmiyyah.

[44] Walsh, K. (2014). Documentary research and evaluation in medical education. $\mathrm{J}$ 
Educ Eval Health Prof, 11, 18. doi:10.3352/jeehp.2014.11.18

[45] Zalani, M. F., \& Omar, A. F. (2019). Kepentingan Prinsip Siyadat Al-shari'ah (Kedaulatan Islam) di dalam Siyasah Syar'iyyah (Politik Islam). Journal of Advanced Research in Social and Behavioural Sciences, 15(1), 69-84.

[46] Zaydān, A. K. (2015). al-Wajīz fī Sharḥ alQawā'id al-Fiqhiyyah fī al-Sharī'ah alIslāmiyyah (1st ed.). Beirut: Muasasat alRisalah Nasyirun. 